\title{
Teenagers in Social Networks: Patterns of Usage and Aggressiveness
}

\author{
Vladimir S. Sobkin and Aleksandra V. Fedotova \\ Center for Sociology of Education \\ "Institute of Education Management \\ of the Russian Academy of Education" \\ 16 Zhukovskogo Str., Moscow, 105062, Russia
}

Received 05.07.2019, received in revised form 26.08.2019, accepted 06.09.2019

The article is devoted to the study of the patterns of network interaction as regards teenagers and their attitude to the aggressive behaviour in social networks.

The article is based on data obtained by specialists of the Center for Sociology of Education of the Institute of Education Management of the Russian Academy of Education as a result of an anonymous survey of 2074 students from grades 5, 7, 9 and 11 of Moscow region schools. Methods of mathematical statistics were used for data processing.

The analysis is aimed at identifying the influence of social, demographic and behavioural characteristics that determine the attitude of teenagers to aggression in social networks.

It has been revealed that the leader's position of a teenager in the class contributes to a greater participation of this teenager in network interaction, which is associated with their motivation to expand their social circle. The growth in the number of provocative statements in the network communication by the time of graduation indicates that the need for manipulation in social relations plays an important role in the process of network communication at this age.

It has been proved that while growing up teenagers start to change the attitude to aggression; the share of high school students who negatively perceive aggression scenes decreases; active users are more likely to show a positive attitude towards aggression scenes, which evidences their "getting used to" the aggressive style of communication on the Internet. Teenagers focused on attracting the attention of others (those who consider their accounts "provocative", "expansive" or "extraordinary") are more likely to enjoy watching violent scenes than the owners of "ordinary" accounts. Personal experience of participating in aggressive situations either in the role of an "aggressor" or a "victim" facilitates their acceptance of aggression. The data presented allow us to conclude that the most significant factors for the creation of the teenagers' attitude to expression of aggression in social networks are their gender, age, frequency of use of social networks, self-presentation on the Internet, social status in the class, estimation of their future success.

(c) Siberian Federal University. All rights reserved

* Corresponding author E-mail address: sobkin@mail.ru

This work is licensed under a Creative Commons Attribution-NonCommercial 4.0 International License (CC BY-NC 4.0). 
Keywords: social networks, adolescence, gender specifics, social status, self-presentation on the Internet, aggression, cyberbullying, active usage of social networks.

Research area: sociology, psychology.

Citation: Sobkin, V.S., Fedotova, A.V. (2019). Teenagers in social networks: patterns of usage and aggressiveness. J. Sib. Fed. Univ. Humanit. soc. sci., 12(9), 1733-1752. DOI: $10.17516 / 1997-1370-0480$.

\section{Introduction}

The teenage years are crucially important for the development of self-awareness, the creation of identity and self-determination (Bozhovich, 2008; El'konin, 1989; Erikson, 1996; Vygotskii, 1984). Because of especially valued communication with peers at this age, the influence of traditional socialization institutions, such as family and school, is downgraded. Moreover, while in the 1990s and early 2000s the researchers noticed that it was various informal youth groups with their subcultural characteristics which occupied the place of family and school (Fedotova, 2004; Sobkin, Fedotova, 2009; Tolstykh, 1991), recently it has been found that the most essential institute of socialization has been the Internet and, in particular, social networks. These very networks make up the main space where the phenomenon of "expansion of the social environment" (which is characteristic of adolescence) occurs. "Street socialization" has been replaced by the so-called information or "digital" one: today, social networks are the place for social processes that characterize the very essence of the transitional age: the importance of interacting with peers and the search for self-identity, learning cultural norms and values, personal self-determination and making life plans (Belinskaia, 2013; Koroleva, 2015; Martsinkovskaia, 2010; Sobkin, Evstigneeva, 2001; Sobkin, 2017; Soldatova, 2018).

The space of social networks for a teenager is described by both independence from adults and at the same time by feeling that there it is possible to act and enjoy freedom in the choice of forms of communication and what is to be expressed. However, it is precisely these features of social networks that give reason to earmark them as a territory of risks associated with a lack of social control. It is not accidental that various tragedies related to teenage suicides or shooting at educational institutions are followed by regular publications emphasizing exactly the influence of social networks on such negative phenomena (Korolenko, Dmitrieva \& Levina, 2014; Mursalieva, 2016). Therefore, the study of cases of teenage aggression in social networks seems to be extremely topical. 
To begin with, we must first and foremost admit that there are two fundamentally different phenomena concerning aggressiveness in social networks. Firstly, this is a demonstration of aggression and posting diverse content in social networks, which may be aggressive in nature; for example, photo and video materials containing scenes of violence, including socially acceptable forms (news stories, ordinary films, sporting events). In this sense, the consideration of the peculiarities of the teenagers' attitude to this kind of content is similar to the study of their attitude to the demonstration of violent and aggressive scenes in the media (Sobkin et al., 2005). In other words, the focus is how teenagers perceive cases of aggression that are not directly related to themselves. Secondly, there can be the aggressive behaviour of users of social networks involving other participants in network interaction and even the respondents themselves (threats, insults, harassment, etc.).

A special niche here is occupied by cyberbullying, which nowadays draws attention of both foreign and Russian researchers (Bochaver, Khlomov, 2014; Griezel et al., 2012; Kowalski, Limber, 2013; Parfent'ev, 2009; Raskauskas, Stoltz, 2007; Smith et al., 2008; Soldatov, L'vova 2018; Soldatova, Shliapnikov, \& Zhurina, 2015; Walrave, Heirman, 2011; Williams, Cheung, \& Choi, 2000). Cyberbullying is a very common, but still not ubiquitous pattern of behaviour for most users of social networks. Aggressive behaviour is manifested here much more habitually with spontaneous, situational, aggressive statements instead of targeted, long-term actions. Such spontaneous aggression is found everywhere in the networks. Active users have already got accustomed to the fact that in social networks, for no apparent reason, one can be subjected to aggression, insults from unfamiliar users for almost any reason. This reaction can be expressed as a statement on any topic (from politics to fashion), a comment on a photo posted somewhere, etc.

This research continues the series of our works directed at studying the characteristics of the information environment of secondary school students, which began as early as at the beginning of the 2000s (Sobkin, Evstigneeva, 2001, 2004a, 2004b). In previous articles dealing with the problem of "teenagers in social networks", we have already analysed issues concerning the motivation of schoolchildren to switch to communication in social networks; the content of their communication on the network; assessment of risks and consequences of using social networks; the impact of network communication on education; social and psychological well-being of teenagers communicating in social networks (Sobkin, 2016, 2017; Sobkin, Fedotova, 2018a, 2018b). In the present work, we will concentrate immediately on issues related to the attitude of teenagers to cases of aggression in social networks. 
The article is based on an anonymous survey of 2074 students of the $5^{\text {th }}, 7^{\text {th }}, 9^{\text {th }}$ and $11^{\text {th }}$ grades of schools in the Moscow region, which was conducted in May 2016 by researchers of the Center for Sociology of Education of the Institute of Education Management of the Russian Academy of Education. We used the special questionnaire containing multiple choice questions, questions with the open answer and scales for evaluation this or that situation. When processing materials, we used methods of mathematical statistics. For statistical analysis of the results we used various criteria to evaluate the significance of differences in responses among different subsamples of respondents.

Materials are grouped in two sections. The first presents general data on the patterns of teenage behaviour in social networks (activity, self-presentation, social distance). The second section depicts the attitude of teenagers to demonstrating scenes of aggression and violence in social networks and their personal experience of participating in situations of aggression in various roles (an aggressor, a victim or a witness). Analysis of the materials obtained was carried out taking into account the influence of the following three groups of factors: demographic (gender, age); the nature of using social networks (activity, intensity, peculiarities of self-presentation on the Internet); social and psychological well-being (status in the class, assessment of the success of one's future).

\section{Discussion}

\section{Social and psychological features of network communication}

In this part, we will touch upon three subjects: the intensity of using the network, self-presentation on the Internet and the orientation of teenagers towards open communication on the network.

1.1. The activity of teenagers in social networks. The data obtained show that $95 \%$ of modern teenagers use social networks. Meanwhile, $90.5 \%$ are registered users and have a personal account (page, blog, etc.), and only $4.1 \%$ use social networks without registration (scrolling news feeds, friends' accounts, etc.). The share of registered users increases markedly from $5^{\text {th }}$ to $7^{\text {th }}$ grade (from $82.0 \%$ to $92.2 \% ; \mathrm{p} \leq .00001$ ).

The question about the activity of using networks was aimed at discovering how much the teenager is involved in the social network, whether teenagers monitor their accounts, update them, etc. Assessing their own activity in social networks, almost half $(47.2 \%)$ attributed themselves to "moderate users" by indicating that they "update their account from time to time, and communicate with friends there." About a third $(31.5 \%)$ 
specified that they are "active users": they constantly monitor their account, update it, regularly communicate there, and seek new friends. Almost one in ten (13.2\%) answered that they use social networks "from time to time", update their accounts rarely, "use them when it is necessary." And finally, only a few (3.9 \%) reported that they rarely use social networks and have never updated their accounts.

When assessing the intensity of using social networks, respondents were asked to indicate directly the amount of time they devote to social networks during the day. More than a third of students (37.9\%) noted that they spend in social networks 1-3 hours daily, and almost a third (31.1\%) spend there less than an hour. A noticeably smaller proportion of teenagers $(13.0 \%)$ spend 5 hours or more in social networks and the share of teenagers who spend in networks from 3 to 5 hours is almost equal $(12.5 \%)$. The share of schoolchildren spending a large amount of time communicating in social networks (from 3 to 5 hours or more) is gradually increasing when they grow up: among students of the $5^{\text {th }}$ grade this share accounts for $13.7 \%$ in total, and among students of the $5^{\text {th }}$ grade this share reaches $36.5 \%$.

Modern gadgets allow one to go online anytime and anywhere. In this connection, we asked schoolchildren the question at what moments and where exactly they usually use social networks. The majority (76.1\%) ticked the answer that they use them at home. About a quarter of teenagers (26.6\%) said they go online anytime. A fifth of the respondents $(19.2 \%)$ go online at school breaks, $10.8 \%$ - while being on the road. And finally, $5.9 \%$ of students admitted they use social networks at the lesson. Teenagers with high social status are more liable to report using networks anytime, anywhere. Also, the habit of using social networks everywhere is aggravated with age (38.0 \% in grade 11 compared to $15.2 \%$ in grade $5 ; \mathrm{p} \leq .00001$ ), and girls are more prone to this behavioural pattern compared to boys ( $30.8 \%$ and $22.1 \%$; $\mathrm{p} \leq .00001)$.

1.2. Self-presentation on the Internet. This topic is of great consequence because it allows researchers to identify such general target orientations of the communicators that determine the nature of their network interaction. Demands of teenagers for their Accounts, what, in their opinion, they should express, are of particular interest here. During the survey, respondents were asked to specify their opinion on what was most important for them when creating their account (page) in the network. The distribution of answers to this question is as follows.

Most often, teenagers strive to ensure that their profile "reflects their personal interests and real image entirely." This option was chosen by $38.7 \%$ of teenagers. About a quarter of respondents $(24.4 \%)$ would like their profile to "express their 
personality." Almost the same number of teenagers are driven by the desire "to draw the interest of closest friends" (24.0\%) when creating their account. Along with that, a very large part of teenagers would like to "avoid unnecessary annoying attention of the other people" (23.8\%). We shall remark that when creating their account $7.9 \%$ of teenagers are oriented towards the norms of behaviour in the social network, which are accepted by their circle: "conformity with the views and positions of the group with which I communicate on social networks". Ultimately it is imperative to emphasize that one in ten $(10.8 \%)$, on the contrary, would like their account to "attract the attention of unfamiliar users".

In general, the answers show the ambiguity of the motives that govern the behaviour of teenagers in social networks: along with the desire to present their real self and interests objectively, they demonstrate the tendency to focus on individual peculiar traits that will attract special interest and probably will help themselves to expand their social circle. In this regard, it is worth mentioning that this trend is most characteristic of these very teenagers who often use social networks. Those who use the networks "occasionally" and "rarely" are more expected to create an account that does not attract the attention of non-friends (respectively: $36.7 \%$ and $32.1 \%$ compared to $15.9 \%$ among active users; $\mathrm{p} \leq$.0005).

So, there is a need for the analysis of the influence of demographic and sociostratification factors. Let us enlist the key points.

First of all, what is interesting here is the choice of the answer, which relates to the teenager's desire to "express their own personality". The analysis of the obtained materials shows that as the teenagers grow older this motive becomes more and more significant: $17.0 \%$ of students of grade 5 and $30.7 \%$ of students of grade 11 wrote about this motive $(\mathrm{p} \leq .00001)$. At the same time, it is typical that the desire to highlight their individuality in the network is more pronounced for girls than for boys $(29.2 \%$ and $19.3 \%$ respectively; $\mathrm{p} \leq .00001$ ).

Such a factor as the social status of the teenager at school has a very peculiar influence on the self-presentation in the network: those who consider themselves to be the class leaders are much more likely than others to focus on attracting the interest of strangers to their account. They also demonstrate greater desire to attract the attention of friends. On the contrary, for those who have only a "limited circle of acquaintances" at school it is much more important "not to attract too much attention" when creating an account: $27.8 \%$ of them chose this answer (compared to $20.9 \%$ among those who stated that they "are respected by many classmates"; $p \leq .002$ ). These trends are presented in Fig. 1. 


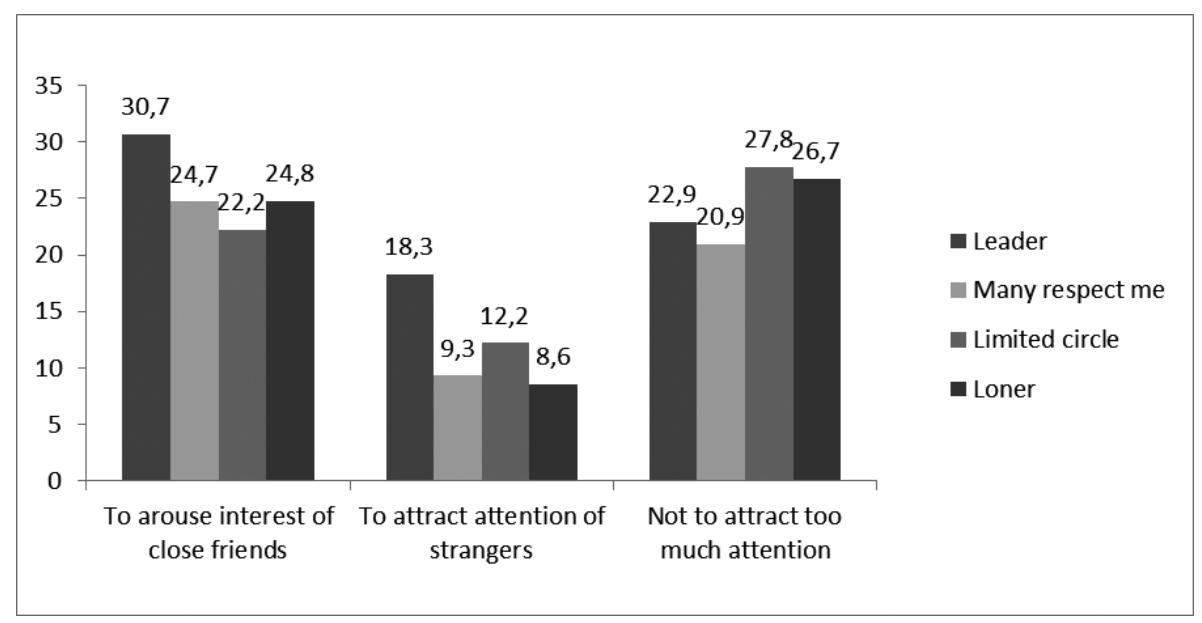

Fig. 1. Various targets for creating an account in a social network: teenagers with different status in the class (\%)

On the whole, the data presented in the figure allow us to conclude that the social position in the class has a profound influence on the target aspects of the teenager's self-presentation in the social network. Obviously, the leader's position turns communication targets both to maintaining existing social ties and to expanding of the social environment.

It should be highlighted that not only traditional social parameters influence the patterns of self-presentation in the network, self-presentation is also modified by general life orientations of teenagers, namely how they evaluate their prospects in terms of success. Teenagers who are optimistic about their future are more often oriented towards presenting their real image in the network than pessimists $(41.2 \%$ and $27.4 \%$ respectively; $\mathrm{p} \leq .01$ ). That means that the positive esteem of their social and psychological well-being encourages representing one's real image in the network. Actually, this trend suggests that psychological self-sufficiency factors contribute into presenting one's real image on the Internet.

1.3. Social distance. During the survey, teenagers were also asked to evaluate their account regarding the degree of its openness. The results show that $24.5 \%$ of respondents described their accounts as "reserved," $8.7 \%$ classified them as "extraordinary", $5.0 \%$ saw them as "expansive", and, finally, $4.4 \%$ admitted their account being "provocative". Nevertheless, the majority of teenagers $(68.3 \%)$ described their account as "ordinary", usual.

Compared to girls, boys are more inclined to daresay that their account in the social network is "expansive" (7.1 \% of boys and $2.9 \%$ of girls; $\mathrm{p} \leq .00001)$ or "provocative" 
( $5.7 \%$ of boys and $3.3 \%$ of girls; $\mathrm{p} \leq .001$ ). Girls more often ticked the option "reserved" ( $27.0 \%$ of girls and $21.9 \%$ of boys; $\mathrm{p} \leq .01$ ).

As for the older children, the share of teenagers who categorized their page as "expansive" decreases and at the same time the proportion of those who believed their account being "extraordinary" increases $(5.7 \%$ of the students of grade 7 and $14.7 \%$ of the students of grade $11 ; \mathrm{p} \leq .00001$ ), the same goes for "provocative" accounts ( $4.1 \%$ of the students in grade 9 and $9.7 \%$ of the students in grade $11 ; \mathrm{p} \leq .0002$ ). Such an increase in provocative attitudes in the network at the stage of graduation is a chief indicator for characterising social and psychological peculiarities of the given age. Indeed, we should take into account that provocation implies influencing a partner in order to provoke a certain reaction and action (often negative) and then we can assume that at this age communication in the network signalises the peculiar need of a teenager to control (manipulate) "social behaviour" of their communication partners. Hence, for a notable number of teenagers network communication acts as a special space for developing their manipulative abilities in the field of social relations.

The next feature to point out is the students' characterization of their account on the Internet, which depends on their targets for creating the account. As it has been mentioned above, when creating an account the teenagers experience two different communicative attitudes: one of them is associated with the desire to "arouse the interest of closest friends", while the other, on the other hand, involves "attracting the attention of unfamiliar users". Let us now consider how the characteristic of the communicator's own page changes depending on these targets.

The data obtained show that teenagers, who are focused on maintaining interest in themselves among their closest friends, in contrast to those who long for attracting the attention of unfamiliar users in a social network, strikingly more often characterize their page as "normal" (68.6\% and 53.5 respectively; $\mathrm{p} \leq .0001)$ or "reserved" ( $28.8 \%$ and $21.5 \%$ respectively; $\mathrm{p} \leq .05$ ). Quite the opposite, those who are intent on attracting the attention of strangers rate their account as "unordinary" $(22.0 \%$ and $10.5 \%$ respectively; $\mathrm{p} \leq .0001)$ or "provocative" (12.6\% and $4.8 \%$ respectively; $\mathrm{p} \leq .0002)$. These trends are graphically presented in Fig. 2.

The figure exemplifies that the wish to expand the social circle (with focus on strangers) is premised on a special model of self-presentation in a social network: the desire to be extraordinary and provoke others. What comes into view is that such non-compliance to norms is correlated with the results of a research aimed at studying the peculiarities of teenagers' self-presentation. It was found that more and more 


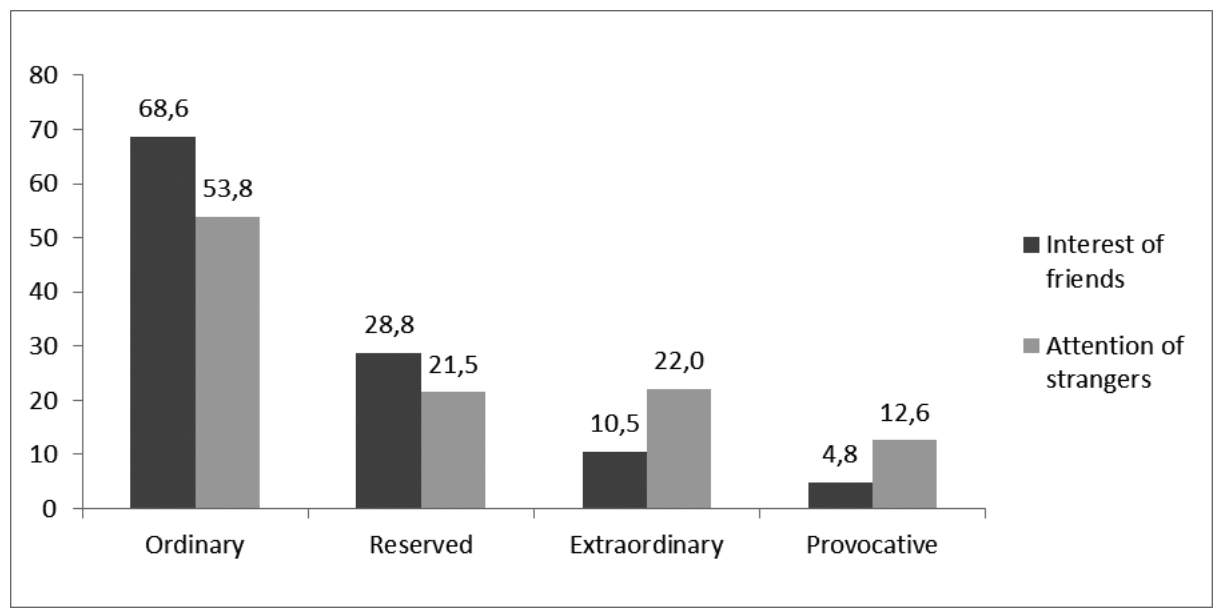

Fig. 2. Differences in the assessment of one's own account in a social network depending on the communicative approach (\%)

teenagers do not comply with behavioural norms while communicating on the Internet (Zhichkina, Belinskaia, 2000). At the same time, we shall remark that, according to our data, this trend is clearly manifested only in such communicative situation which involves network interaction with strangers. And this, in our opinion, is a major rectification of the peculiarities of this trend of non-normative self-presentation on the Internet. Conversely, a teenager who mostly interacts with the circle of the closest friends when communicating in the network does not go beyond the norms that have developed in this circle of communication. Such teenagers labelled their accounts as "ordinary" and "reserved".

And eventually, concluding this section, we should make a point that the way teenagers characterize their accounts in the network depends on their social status among classmates. Thus, leaders are totally different from those students who have a limited circle of friends with respect to the "originality" indicator $(17.0 \%$ and $7.7 \%$ respectively; $\mathrm{p} \leq .001)$ and "provocativeness" indicator $(11.8 \%$ and $3.7 \%$ respectively; $\mathrm{p} \leq$.00001). This makes it possible to expound the above conclusion that among the leaders there is a more pronounced tendency to expand their social circle in the space of network communication. The reason is that such an "expansion" is associated with the desire to realize their need for social manipulation. 


\section{Factors affecting teenage aggression in social networks}

In this section we will consider two aspects. The first one concerns the positive or negative attitude of teenagers to scenes of violence in social networks; the second is related to their personal experience of participating in situations of aggression in the networks.

2.1. Attitude towards aggression. Teenagers' answers to the question of how they feel about violent scenes broadcast through social networks show that most of them (66.1\%) "dislike" seeing violent scenes in social networks. A quarter of the respondents $(25.4 \%)$ wrote that they are "indifferent" to such scenes. Almost every tenth showed a positive attitude: $6.3 \%$ indicated that they "like" to watch these scenes and $2.3 \%$ "specially choose" the pages where violent scenes are shown.

Traditionally, male and female subcultures habitually demonstrate different attitudes towards violence. In this regard, the expected result is that girls are much more certain to perceive scenes of violence negatively (76.4\% compared to $55.2 \%$ among boys; $\mathrm{p} \leq$.00001). Thereby boys' and girls' content in social network differs significantly due to their attitude to the expression of aggressiveness.

As for age dynamics, the most noticeable shifts in the attitude of teenagers towards demonstrating scenes of violence in social networks occur after grade 7 (see Fig. 3).

It can be seen from the figure that by the end of secondary school (from grade 7 to grade 9), the share of those who "dislike" watching violent scenes shrinks and the number of those for whom scenes of violence do not matter enlarges $(\mathrm{p} \leq .001)$.

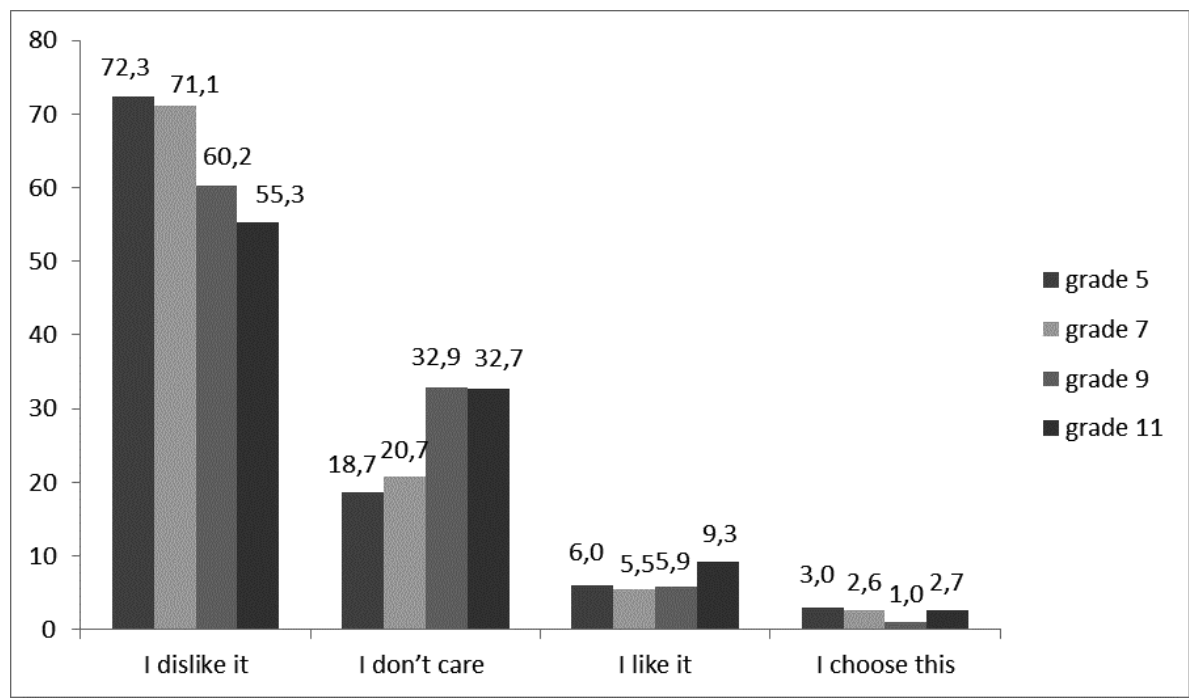

Fig. 3. Age dynamics of teenagers' attitudes to violence in social networks (\%) 
Concurrently, the number of schoolchildren who have an utterly positive attitude to the scenes of violence ("I like it" and "I choose this") barely changes throughout adolescence.

In addition to gender and age-related characteristics, we should give thought to perception of aggressive and violent scenes in the network depending on behavioural characteristics (activity and intensity of using the network, self-presentation on the Internet) and social and psychological factors (status in the class, emotional assessment of life prospects).

The data we got show that teenagers who see themselves as active users of social networks are more tolerant to demonstrating violence and aggression in social networks. They more often choose answer "I like it" (9.8 \% compared to $2.2 \%$ among those who use networks "from time to time"; $\mathrm{p} \leq .00001)$ and "I don't care" $(29.2 \%$ compared to $20.4 \%$ among those who use networks from occasionally; $\mathrm{p} \leq .005$ ); and less often - "I dislike it" (58.4\% and $74.4 \%$ respectively; $\mathrm{p} \leq .05)$. The dependence on the time spent in social networks daily is also displayed in a similar way.

Furthermore, the attitude of teenagers to the expression of aggression depends on the nature of self-presentation in the networks. So, among students who consider their accounts in the networks being "provocative", "expansive" or "extraordinary" the percentage of those who "like" to see violent scenes in social networks is distinctly higher than among those who consider their accounts "ordinary" (26.1 \%, $20.4 \%$, $15.5 \%$ and $4.2 \%$ respectively; $\mathrm{p} \leq .00001)$. Overall, the desire to attract attention, to be expansive and extraordinary in a social network for many teenagers is often associated with showing approval for the cases of violence and aggression in social networks. In other words, the very orientation of a teenager to active participation in network communication ("attracting attention to oneself") to a large extent implies involvement in a situation with aggressive interaction.

An analysis related to evaluating the position of a teenager at school showed that among those teenagers who play the roles of "leaders" and "outcasts" ("loners") in the class, the percentage of those who perceive violent scenes in social networks positively is higher. "Leaders" and "loners" more often indicated that they "like" to see such scenes (12.4\% and $14.3 \%$ respectively, compared to $5.7 \%$ among those with an average status in the group; $\mathrm{p} \leq .01$ ). They also more frequently pointed out that they "specifically choose" exactly those pages showing violent scenes (4.6\% and $6.7 \%$ respectively, compared with $1.4 \%$ among students with an average status in the group; $\mathrm{p} \leq .03$ ). To sum up, we can conclude that the teenager's start of network communication 
is also associated with the desire to solve here problems associated with their own social position in the class, and aggression might be the key. A more detailed analysis showed that teenagers who identify themselves as "leaders" and "loners" are more emotionally involved in the situation of network aggression: they more often identify themselves as "aggressors" (11.1 \% and $15.2 \%$ compared to $6.0 \%$ among students with an average status in the group; $\mathrm{p} \leq .03)$ and "victims" (11.8\% among leaders and $6.8 \%$ among students with an average status; $\mathrm{p} \leq .04$ ). This can lead to the assumption that aggression in network communication is often an extension of real conflicts in the class associated with social and role status in the group. Moreover, not only "loners" but also "leaders" are at risk here. Another way of putting it is that there is a struggle for higher status positions in the group.

And finally, among teenagers who are pessimistic about their own future, the proportion of those who opt for seeing aggressive scenes is higher $(13.0 \%$ compared to $6.0 \%$ among "optimists"; $\mathrm{p} \leq .02$ ); what is more, pessimists more often choose such scenes "specially" ( $9.1 \%$ as compared to $1.6 \%$ among optimists respectively; $\mathrm{p} \leq$ $.0001)$. As a consequence, we can suppose that the teenagers' perception of their own future in a negative way is one of the factors contributing to the creation of a positive attitude towards aggression and violence. In other words, aggression in the network performs a compensatory function, in connection with a general negative evaluation of the possibility of teenagers' success in future.

Yet another indicator is the teenagers' willingness to demonstrate empathy ("sympathy") as regards victims of violent scenes seen in the network. The results show that, all in all, most teenagers (59.2\%) tend to "always sympathize with the victims of violence". $19.4 \%$ of teenagers sympathize only when "it concerns their friends". At the same time, one in five (21.4\%) indicated that "they never feel sympathy for the victims" in scenes of aggression seen in the social networks.

The expression of sympathy for the victim is clearly exposed to the intensity of the teenager's participation in network communication (see Fig. 4).

From the data in the figure it can be seen that as the intensity of network communication increases, the proportion of teenagers who sympathize with the victim of aggression self-evidently decreases. Due to this, we can conclude that the result of active participation in network communication is a kind of adaptation ("acquiring the ability to be thick-skinned") to acts of aggression in the network.

2.2. Personal experience of facing aggression in social networks. Addressing the question of personal experience - a direct encounter of teenagers with situations of 


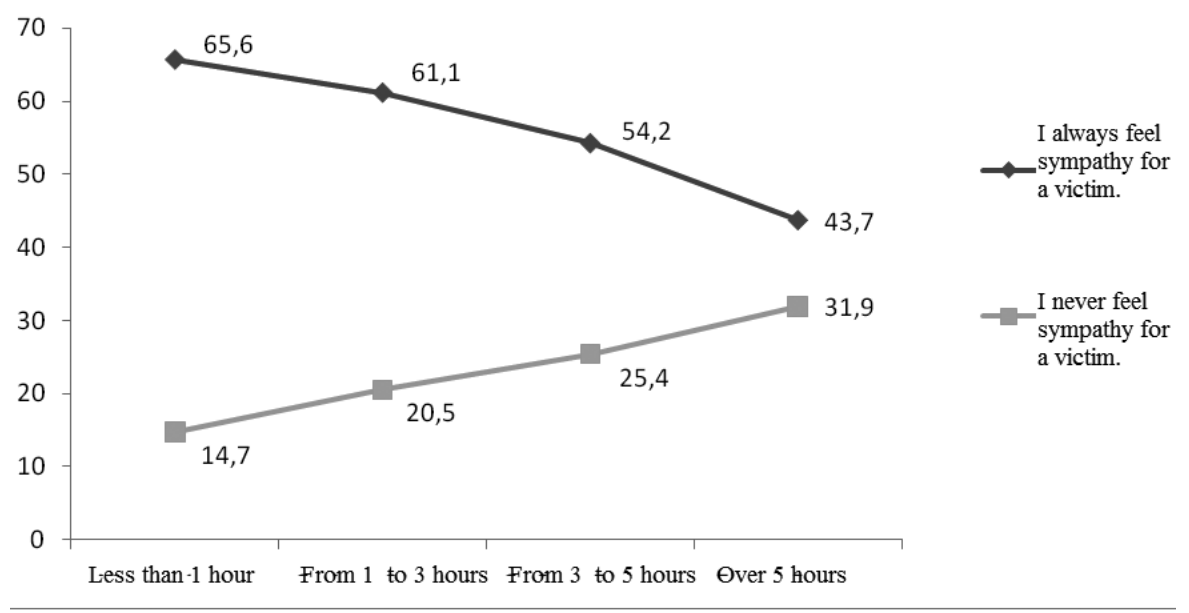

Fig. 4. Sympathy for victims of violence depending on the intensity of everyday use of social networks $(\%)$

aggression in social networks, we get the following results: almost one in three (31.1\%) had to experience "aggression from other users". The fifth part (21.1\%) indicated that they were witnesses of aggression against other users. $6.0 \%$ of respondents admitted that "they themselves acted as aggressors against other users". And finally, a little more than a third of teenagers (36.1\%) stated that they had never faced aggression in social networks.

Virtual communication for boys is characterized by greater aggressiveness: they more often, as compared to girls, acknowledged that they acted as aggressors, too ( $7.5 \%$ and $4.5 \%$ respectively; $\mathrm{p} \leq .01)$, and became victims $(34.0 \%$ and $28.2 \%$ respectively; $\mathrm{p} \leq$.003). Obviously, the rougher approach to interaction, which inherent in boys in real life, is transferred to the network communication.

The study of age dynamics allows us to establish a clear shift towards an increase in the aggressiveness in the network at the end of grade 7: the proportion of those who witnessed aggression in grade 5 is $13.0 \%$ and among students in grade 7 it is much higher $-21.5 \%$ ( $\mathrm{p} \leq .0001)$. To put it simply, the teenage crisis (puberty) also comes to the fore in the space of network interaction.

The resulting data show that the personal participation of a teenager in situations of network aggression apparently depends on the intensity of his/her communication on the Internet (see Fig. 5).

The figure vividly shows that with an increase in the intensity of network communication, the share of those who fell victim to aggressive behaviour in the 


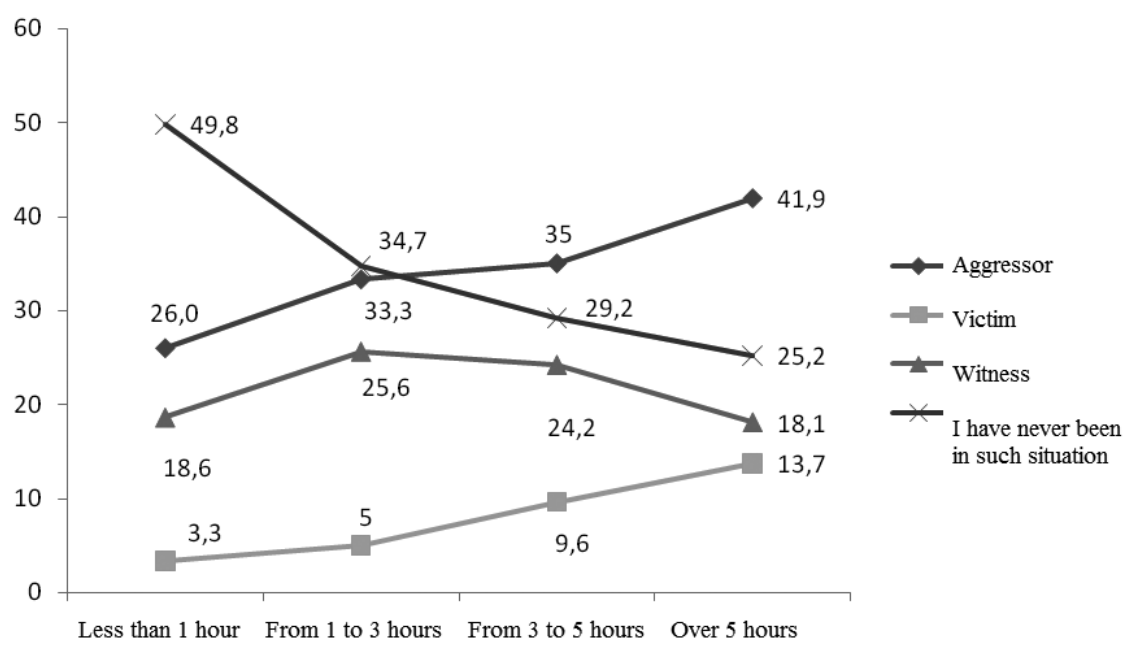

Fig. 5. Teenagers' experience of a situation of network aggression in one role or another, depending on the intensity of everyday use of social networks (\%)

network increases, too $(26.0 \%$ among those who communicate in the network for less than 1 hour and $41.9 \%$ among those who spend more than 5 hours in the network; $\mathrm{p} \leq .00001)$. The share of aggressors is also growing (3.3\% and $13.7 \%$ respectively; $\mathrm{p} \leq .00001)$.

In addition to the intensity of communication, the character of self-presentation on the Internet also holds its meaning. For instance, teenagers who "want to attract the attention of unfamiliar users" to their account more often acted as aggressors (11.7 \% compared to $5.1 \%$ among those whose account reflects their real images; $\mathrm{p} \leq .0002$ ). Those who consider their accounts "interesting to strangers" were the most often attacked by other users, while teenagers who characterized their accounts as "reserved" were the least often attacked $(39.4 \%$ and $30.8 \% ; \mathrm{p} \leq .05)$. Thereby, the above mentioned data show that self-presentation on the Internet is a vital factor determining the nature of a teenager's participation in an aggressive situation in the space of network communication. Along with this, the orientation toward individualization of one's profile (originality, the desire to attract attention) provokes increased aggression from network users.

And, finally, special attention, in our opinion, should be paid to differences related to the social status of a teenager in the class. For example, while $28.1 \%$ of "leaders" told that they at least once acted as objects of aggression from other network users, among the "loners" the share of "victims of aggression" is not less than $41.9 \%$ $(\mathrm{p} \leq .02)$. It should be added that the boys show the direct correlation between the 
leader's position and the role of aggressor: $20.0 \%$ of leaders compared to $9.0 \%$ among those with a "limited circle of friends" ( $\mathrm{p} \leq .003)$. Single boys ("loners") also more often acted as aggressors - $15.0 \%$ (more often than those who indicated that "many classmates respect me"; $\mathrm{p} \leq .005$ ), which justifies the severity of social and status conflicts among teenage boys. In general, the materials obtained give the basis for the conclusion that the network communication of a teenager substantially depends on real social and role relations at school; without a doubt, already existing conflicts continue in network communication.

We attach importance to how the attitude of teenagers to the scenes of violence and aggression shown in the network changes depending on their personal experience of participating in such situations in the role of an "aggressor", a "victim" or a "witness".

The data we obtained show that among teenagers who have acted as "aggressors", the percentage of those who enjoy watching violent scenes is impressively higher (20.2\% compared with $3.4 \%$ among "witnesses"; $\mathrm{p} \leq .00001)$. And this is quite foreseeable. At the same time, it should be set out that among those teenagers who suffered from being a "victim" of aggression in social networks, this percentage is also conspicuously higher than among "witnesses" (9.8\% and $3.4 \%$ respectively; $\mathrm{p} \leq$ .00001). Perhaps, this kind of reaction is caused by compensatory mechanisms.

And finally, finishing the article, we will elucidate another aspect that concerns the sympathy for the victim. The survey data show that teenagers who had the experience of being aggressors are much less bound to show sympathy for the victim — only $34.7 \%$ in this category (as compared to $61.8 \%$ among "victims"; $57.9 \%$ among "witnesses"; $\mathrm{p} \leq$. 00001). All the while, "aggressors" more often indicated that they never feel sympathy for the victim - $46.8 \%$ of such students (as compared to $18.0 \%$ among "victims"; $15.3 \%$ among "witnesses"; $\mathrm{p} \leq .00001$ ). Thus, the personal experience of participation (regardless of the role) in situations of aggression (either in the position of an "aggressor" or a "victim") substantially determines the expression of emotional sympathy for the victim.

\section{Conclusion}

The study results allow us to draw the following main conclusions.

1. The data obtained testify that the use of social networks is a trivial thing for modern teenagers. Moreover, while getting older they get more and more involved in social networks: the intensity of network communication grows and the habit of using social networks everywhere aggravates. 
2. The study showed that the social and psychological factors (status in the class, evaluation of one's life prospects) significantly affect peculiarities of self-presentation on the Internet as well as gender and age factors. At the same time, network communication for a sizeable number of teenagers becomes a special space for the realization of their manipulative abilities in the field of social relations. It is typical that the expansion of the social environment in the social network is associated with the increased tendency to behave breaking the accepted norms.

3. Attitude to aggressiveness in the network is strikingly different for boys and girls, which confirms the distinction between the existing male and female subcultures in social networks. This difference is also illustrative regarding the willingness to sympathize with the victims of aggression.

4. Network communication of a teenager depends mainly on real social relations and roles played at school; existing conflicts continue in network communication. Along with this, the space of network communication turns out to be an area for participation in processes associated with the struggle for social status, which has started in real interaction with classmates.

5. The study showed that not only gender and age factors, but also behavioural factors such as self-presentation, activity and intensity of participation in network communication have a direct influence on the teenagers' attitude to network aggression. Orientation of teenagers to active network communication to a considerable extent implies their involvement in a situation with aggressive interaction. At the same time, it was established a relationship between the orientation toward abnormal behaviour ("provocation") and a reduced sensitivity to the significance of possible aggressive responses.

6. The decisive role in relation to aggression in the network is played by the personal experience of a teenager. Participation in an aggressive interaction, depending on the position taken (either an "aggressor" or a "victim") determines exactly the expression of emotional sympathy in situations of network aggression.

\section{References}

Belinskaia, E.P. (2013). Informatsionnaia sotsializatsiia podrostkov: opyt pol'zovaniia sotsial'nymi setiami i psikhologicheskoe blagopoluchie [Informational socialization of teenagers: the experience of using social networks and psychological well-being]. In Psikhologicheskie issledovaniia [Psychological studies], 6(30), available at http://psystudy.ru/index.php/num/2013v6n30/858-belinskaya30.html (accessed 15 April 2019). 
Bochaver, A.A., Khlomov, K.D. (2014). Kiberbulling: travlia v prostranstve sovremennykh tekhnologii [Cyberbullying: Harassment in the space of modern technologies]. In Psikhologiya. Zhurnal Vysshei shkoly ekonomiki [Psychology. Journal of the Higher School of Economics], 11(3), 178-191.

Bozhovich, L.I. (2008). Lichnost' $i$ ee formirovanie v detskom vozraste [Personality and its formation in childhood]. Saint-Petersburg, "Piter", 398 p.

El'konin, D.B. (1989). Izbrannye psikhologicheskie trudy [Selected psychological works]. Moscow, "Pedagogika", 560 p.

Erikson, E. (1996). Identichnos': iunost' i krizis [Identity: Youth and crisis]. Moscow, Izd. gruppa "Progress", 344 p.

Fedotova, A.V. (2004). Neformal'nye molodezhnye gruppy v sovremennoi podrostkovoi subkul'ture [Informal youth groups in modern teenage subculture]. In Nachal'naia shkola plius do i posle [Primary school plus before and after], 3, 11-16.

Griezel, L., Finger, L.R., Bodkin-Andrews, G.H., Craven, R.G., \&Yeung, A.S. (2012). Uncovering the structure of gender and developmental differences in cyber bullying. In The Journal of Educational Research, 105(6), 442-455. DOI: 10.1080/00220671.2011.629692

Korolenko, Ts.P., Dmitrieva, N.V., \& Levina, L.V. (2014). K voprosu o vliianii Interneta na suitsidal'noe povedenie [On the issue of the Internet's impact on suicidal behavior], In Uchenye zapiski SPbGIPSR [The Scientific Notes of St. Petersburg State Institute of Psychology and Social Work], 22(2), 103-107.

Koroleva, D.O. (2015). Ispol'zovanie sotsial'nykh setei v obrazovanii i sotsializatsii podrostka: analiticheskii obzor empiricheskikh issledovanii (mezhdunarodnyi opyt) [The use of social networks in education and socialization of teenagers: an analytical review of empirical studies (international experience)]. In Psikhologicheskaia nauka i obrazovanie [Psychological Science and Education], 20(1), 28-37. DOI:10.17759/ pse. 2015200104.

Kowalski, R.M., Limber, S.P. (2013). Psychological, Physical, and Academic Correlates of Cyberbullying and Traditional Bullying. In Journal of Teenager Health, $53,13-20$.

Martsinkovskaia, T.D. (2010). Informatsionnoe prostranstvo kak factor sotsializatsii sovremennykh podrostkov [Information space as a factor of modern teenagers' socialization]. In Mir Psikhologii [The World of Psychology], 3, 90-102.

Mursalieva, G. (2016). Gruppy smerti [The death groups]. In Novaia gazeta [New Paper], 51, 2-5. 
Parfent'ev, U. (2009). Kiber-agressory [Cyber-agressors]. In Deti v informatsionnom obshchestve [Children in the information society], 2, 66-67.

Raskauskas, J., Stoltz, A.D. (2007). Involvement in Traditional and Electronic Bullying Among Teenagers. In Developmental Psychology, 43(3), 564-575.

Smith, P.K., Mahdavi, J., Carvalho, M., Fisher, S., Russel, S., \& Tippett, N. (2008). Cyber bullying: Its nature and impact in secondary school pupils. In Journal of Child and Psychiatry, 49, 376-385.

Sobkin, V.S. (2016). Sovremennyi podrostok v sotsial'nykh setyakh [The modern teenager in social networks]. In Pedagogika [Pedagogics], 8, 61-72.

Sobkin, V.S. (2017). Podrostok: vkliuchennost' v setevoe vzaimodeistvie i otnoshenie k obrazovaniiu [Teenager: involvement into virtual interaction and attitude to education]. In Kommunikatsii. Media. Dizain [Communications. Media. Design], 2(2), 99-113.

Sobkin, V.S. Abrosimova, Z.B., Adamchuk, D.V., \& Baranova, E.V. (2005). Podrostok: normy, riski, deviatsii. Trudy po sotsiologii obrazovaniia, X, XVII. [Teenager: norms, risks, deviations. Works on the sociology of education], X (17). Moscow, Tsentr sotsiologii obrazovaniia RAO, 359 p.

Sobkin, V.S., Evstigneeva, Iu.M. (2004). The Teenager: Virtual and Social Reality. In Russian Education and Society, 46(6), 6-100.

Sobkin, V.S., Evstigneeva, Iu.M. (2004). The Teenager: Virtual and Social Reality. In Russian Education and Society, 46(7), 3-92.

Sobkin, V.S., Evstigneeva, Yu.M. (2001). Podrostok: virtual'nost' i sotsial'naia real'nost'. Po materialam sotsiologicheskogo issledovaniia. Trudy po sotsiologii obrazovaniia, VI, X. [Teenager: Virtual and social reality. Based on sociological survey. Works on the sociology of education], VI (10). Moscow, Institut sotsiologii obrazovaniia RAO, $156 \mathrm{p}$.

Sobkin, V.S., Fedotova, A.V. (2009). Podrostok-neformal: prinadlezhnost' k gruppe i zhiznennye orientatsii [Teenager belonging to a subculture: group affiliation and life values]. In Sotsiologiia obrazovaniia. Trudy po sotsiologii obrazovaniia, XIII, XXII [Sociology of education. Works on the sociology of education], XIII (22). Moscow, Institut sotsiologii obrazovaniia RAO, 84-101.

Sobkin, V.S., Fedotova, A.V. (2018). Podrostok v sotsial'nykh setiakh: k voprosu o sotsial'no-psikhologicheskom samochuvstvii [Teenager in social networks: on the issue of social and psychological well-being]. In Natsional'nyi psikhologicheskii zhurnal [National Psychological Journal], 3(31), 23-36. DOI: 10.11621/npj.2018.0303. 
Sobkin, V.S., Fedotova, A.V. (2018). Podrostok v sotsial'nykh setiakh: riski i reaktsii [Teenager and social networking: risks and response]. In Voprosy psikhicheskogo zdorov'ia detei i podrostkov [Issues of mental health of children and teenagers], 1, 47-56.

Soldatova, G.U. (2018). Tsifrovaia sotsializatsiia v kul'turno-istoricheskoi paradigme: izmeniaiushchiisa rebenok $\mathrm{v}$ izmeniaiushchemsia mire [Digital socialization in the cultural and historical paradigm: a changing child in a changing world]. In Sotsial'naia psikhologiia i obshchestvo [Social psychology and society], 9(3), 71-80. DOI:10.17759/sps.2018090308.

Soldatova, G.U., L'vova, E.N. (2018). Osobennosti roditel'skoi mediatsii v situatsiiakh stolknoveniia podrostkov s onlain-riskami [Teenagers encountering online risks: characteristics of parental mediation]. In Psikhologicheskaia nauka i obrazovanie [Psychological science and education], 23(3), 29-41. DOI:10.17759/pse.2018230303.

Soldatova, G.U., Shliapnikov, V.N., \& Zhurina, M.A. (2015). Evoliutsiia onlainriskov: itogi piatiletnei raboty linii pomoshchi "Deti Onlain" [The evolution of online-risks: the results of helpline "Kids Online": five-year work experience]. In Konsul'tativnaia psikhologiia $i$ psikhoterapiia [Counseling psychology and psychotherapy], 23(3), 50-66. DOI:10.17759/cpp.2015230304.

Tolstykh, A.V. (1991). Podrostok v neformal'noi gruppe [Teenager in subculture group]. Moscow, "Znanie”, 80 p.

Vygotskii, L.S. (1984). Pedologiia podrostka [Paedology of the teenager]. In L.S. Vygotskii. Sobranie sochinenii v 6 t. T. 4. Detskaia psikhologiia [L. S. Vygotsky. Collected works: in 6 vol. Vol. 4. Child psychology]. Moscow, "Pedagogika", 5-242.

Walrave, M., Heirman, W. (2011). Cyberbullying: Predicting victimization and perpetration. In Children \& Society, 25(1), 59-72. DOI: 10.1111/j.10990860.2009.00260.x

Williams, K., Cheung, C.K. T., \& Choi, W. (2000). Cyberostracism: Effects of being ignored over the Internet. In Journal of Personality and Social Psychology, 40, 303-311.

Zhichkina A.E., Belinskaia E.P. (2000). Samoprezentatsiia v virtual'noi kommunikatsii i osobennosti identichnosti podrostkov-pol'zovatelei Interneta [Selfpresentation in virtual communication and features of identity of teenagers using the Internet]. In Obrazovanie i informatsionnaia kul'tura. Sotsiologicheskie aspekty. Trudy po sotsiologii obrazovaniia [Education and information culture. Sociological aspects. Works on the sociology of education], V (17). Moscow, Tsentr sotsiologii obrazovaniia RAO, 431-460. 


\title{
Подросток в социальных сетях: \\ особенности пользования и агрессивность
}

\author{
В. С. Собкин, А. В. Федотова \\ Центр сочзиологии образования \\ Институт управления образованием \\ Российской академии образования \\ Россия, 105062, Москва, ул. Жуковского, 16
}

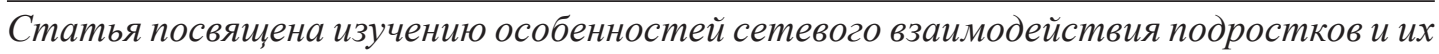
отношения к проявлениям агрессии в социальных сетях.

В основу статьи легли данные, полученные сотрудниками Центра сочиологии образования «Института управления образованием Российской академии образования» в ходе анонимного анкетного опроса 2074 учашихся 5, 7, 9 и 11 классов школ московской области. При обработке данных использовали методы математической статистики. Анализ результатов направлен на выявление влияния сочиально-демографических u поведенческих характеристик, определяюших отношение подростков к агрессии в сочиальных сетях.
\end{abstract}

Выявлено, что лидерская позиция в коллективе класса в большей степени ориентирует подростка на сетевое взаимодействие, связанное с мотивацией расширения его социальной среды. Рост провокативных установок при общении в сети на этапе окончания школь свидетельствует о том, что в прочессе сетевого общения на этом возрастном этапе важную роль играет потребность в манипулящии в сфере социальных отношений.

Показано, что с возрастом уменьшается доля подростков, негативно воспринимающзих сиены агрессии; активные пользователи чаще проявляют позитивное отношение к таким сиенам, что свидетельствует о «привыкании» к агрессивной стилистике общения в Интернете. Подростки, ориентированные на привлечение внимания окружающих (те, кто считает свои профили «провокационными», «откровенными» или «неординарными»), чаще получают удовольствие от просмотра сцен насилия, чем владельцы «обычных» страниц. Наличие у подростков опыта участия в ситуациях агрессии в роли «агрессора» или «жертвы» способствует принятию ими агрессии.

Приведеннье даннье позволяют сделать вывод о ведущей роли в формировании отночения подростков к проявлениям агрессии в сочиальных сетях таких факторов, как пол, возраст, интенсивность пользования сочиальными сетями, самопрезентация в сети, социальный статус в классе, оченка своей будущей успешности.

Ключевые слова: социальные сети, подростковый возраст, гендерная специфика, социиальный статус, самопрезентация в сети, агрессия, кибербуллинг, активность пользования сочиальными сетями.

Научная специальность: 22.00.00 - социологические науки; 19.00.00- психологические науки. 